\title{
EXPERIMENTAL EVALUATION A TENSILE STRENGTH OF PAFSIN PIPES IN DIFFERENT TYPES OF LAND
}

\author{
Ana Diana Ancas ${ }^{\text {a, }}$, M. Profire ${ }^{\text {a }}$, G. Cojocaru ${ }^{\text {b }}$ \\ $\mathrm{a}^{*}$ Technical University "Ghe. Asachi" of Iasi, Faculty of Civil Engineering and Building Servicies, Department Building Sevicies, \\ 67 D. Mangeron, 700050, Romania, e-mail: ancas05@yahoo.com \\ ${ }^{\mathrm{b}}$ Romstal, 8 Spiru Haret, Bacău, Romania
}

Received: 14.092017 / Accepted: 30.09.2017 / Revised: 31.10.2017 / Available online: 15.12.2017

DOI: 10.1515/jaes-2017-0007

KEY WORDS: PAFSIN, experimental evaluation, axial stresse, types of land

\begin{abstract}
:
Most studies on the PAFSIN pipes were oriented monitoring their behavior in laboratory conditions, focusing on the fluid and less influence on the environment laying on the mechanical properties in the short term then extrapolated mathematical term. Moreover, a large part of these studies refer only to the effect on PAFSIN composite samples without taking into account the specificities induced specific geometry pipeline. In this way, the effect PAFSIN pipes can be overlooked, which in practice can lead to significant errors of design and / or execution. Compared to existing studies, taking into account only the effect of a sealant (generally standardized solutions of acid or base) of the PAFSIN pipes, in the article to present the results of tests conducted on PAFSIN pipes buried in different types of land and attempted to surprise the complexity of the interactions of soil solution to the conduit.
\end{abstract}

\section{INTRODUCTION}

Pipes PAFSIN (polyester reinforced fiberglass and insert sand) were invented in the mid-twentieth century, as an application of composite PAFSIN (turn invented before the Second World War the corporation Owen Corning) (Isama, 2013). The first applications of these pipelines were in the chemical and petrochemical, and as improving production technology (allowing cost reduction) began to be used in urban sewage networks and water supply (Sindhu, 2007, Cojocaru, 2017).

In Romania this pipeline began to be produced in the 1980's anticorrosion Bucharest after method, with use in drains and sewers of large industrial complexes (Mateescu et al., 2000). Using massive utility networks in our country began in 1997, with a feed water Fagaras, reaching as today using PAFSIN pipes be technical solution standard for a size range between DN150 and DN3200 (largest diameter used in Romania). Basically there are counties where there is no work done with this type of pipes, drains, water supply, hydropower, heat register or water management.

The extensive use of this type of pipe, in its various embodiments, has led to the need to investigate their behavior in the land, which causes man-made or natural, have different values of $\mathrm{pH}$ to neutral.
If some faults may be attributed to errors in mounting / laying, and the like on the degradation characteristics of the minimum necessary filler (especially in the case of pollution phenomena active), there are, however, clearly questions about the effect of ground pollution, and in particular the $\mathrm{pH}$ of the solution that land on PAFSIN pipes. Just these influences are addressed by the present work steps, while the literature focuses more on the influence of the fluid on PAFSIN pipes and only passenger on physico-chemical interaction pitch-pipe.

\section{PAFSIN COMPOSIT MATERIAL}

Material generically called PAFSIN (glass fiber reinforced polyester and embedded sand) or GRP (glass reinforced plastic) is classified materials. The composition comprises: heat curing resin, glass fiber, sometimes quartz sand (silicon dioxide of at least 98\%). Unsaturated polyester resins can be (orthophthalic or isophthalic), vinyl ester, bisphenol, or epoxy. If the cooperation of the matrix of fiber glass and resin mass, possibly with the insertion of sand, it is crucial to achieve the functional purposes of the composite wide range of possible combinations between these components generate one of the key advantages of the composite GRP adaptability to the situation in of land by developing a manufacturing recipes appropriate practical needs (Stamenovic et al., 2011, Wang et al., 2103). In most cases, the glass fiber used is of the type calcium aluminosilicate (type E). If the enhanced chemical resistance is required, use of glass

\footnotetext{
* Corresponding author. ANCAS ANA DIANA, e-mail: ancas05@yahoo.com
} 
fiber type $\mathrm{C}$, containing boron trioxide. The use of thermal curing of the resin is incurred heat of chemical reactions that form the final shape molecules, which leads to excellent resistance to fire. Other characteristics of the composite GRP are resistant to chemical aggressions, lightweight, UV-resistant, non-corrosive electrical insulator, permeable to radio frequencies, sound insulator, relatively low cost price (Moser and Alma P., 2001).

\section{THEORETICAL EVALUATION BEHAVIOR OF PAFSIN PIPES}

The theoretical evaluation has used German standard recommendations (Akimwumi and Diwa,, 2014, Adams and Cawley, 1998). It calculates the rigidity of the pipes, coatings and type bed laying. It allows the user to select a different input; such calculation can be adapted to existing concrete to data availability. In practice it often happens that information about installation conditions and / or type of soil is not very accurate, so the selection input is up to the engineer, but standard issuing recommendations in this regard. Based on the calculation model static accepted for GRP, the cooperation header to the pipes is essential (for the purpose of taking over a part of the load of the filler material to the parameters of the compacting comparable with the field undisturbed), the transition to a rigid behavior would result in the loss of this advantage (David-West et al., 2008). Concrete, there is a possibility that a certain PAFSIN pipe (with a predetermined nominal stiffness), in certain load conditions (traffic, weight / thrust earth) to meet the specific checking statically elastic pipe (which require maximum allowable deflection), but not specific static verifications pass a rigid pipes (working with the land is not taken into account and set a maximum allowable effort) (Mertiny et al., 2007).

\subsection{Mathematical operator used}

Given the multitude of variables involved in the analysis of the influence of soil on GRP pipe ( $\mathrm{pH}$, alkaline earth metal ions, salts, etc.), simple empirical investigation of the interaction of the experimental data to generate conclusions on the type of cause and effect is not sufficient (Hornung, and Kittel, 2010, Shukry et al., 2013). Therefore, the call to an apparatus capable of mathematically possible to highlight correlations of experimental data is necessary (Rafiee, 2013). To this end, we used the Pearson correlation coefficient as a measure of linear dependence between two sets of variables. They were developed by Karl Pearson, early twentieth century.

If we have two rows of data: $\left\{\mathrm{x}_{1} \ldots \ldots . \mathrm{x}_{2}\right\}$, respectively $\left\{\mathrm{y}_{1} \ldots \ldots \ldots \mathrm{y}_{2}\right\}$ then, the Pearson correlation coefficient is:

$$
r=\frac{\sum_{i=1}^{\mathrm{n}}\left(x_{1}-\bar{x}\right)\left(y_{1}-\bar{y}\right)}{\sqrt{\sum_{\mathrm{i}=1}^{\mathrm{n}}\left(x_{1}-\bar{x}\right)^{2}} \sqrt{\sum_{\mathrm{i}=1}^{\mathrm{n}}\left(y_{1}-\bar{y}\right)^{2}}}
$$

$$
\bar{x}=\frac{1}{\mathrm{n}} \sum_{i=1}^{\mathrm{n}} \mathrm{x}_{\mathrm{i}}
$$

respectively:

$$
\bar{y}=\frac{1}{\mathrm{n}} \sum_{i=1}^{\mathrm{n}} \mathrm{y}_{\mathrm{i}}
$$

they are average values of $x$ and $y$ (Renoud, et al., 2009).

The absolute values of " $r$ " can be less than or equal to 1 . A correlation coefficient is equal to $l$ indicates a perfect direct linear connection between two rows of data, while a value of $" r$ " equal to - 1 will show a perfect inverse linear relation between them. A value of 0 indicates lack of any correlation between data streams. In practice, a value greater than 0.8 is considered to designate a correlation clear enough to be recorded. In order to clarify some aspects of the influence of the field on pipelines PAFSIN, I acquired on April 24, 2014 a pipe PAFSIN DN150, PN10, SN10000, 6m, manufactured using a winding (filament winding) company Amitech at its plant in Dresden, Germany. The wires were cut from three sections of length of about $150 \mathrm{~cm}$, which has been installed in the three experimental blocks at a depth of approximate $90 \mathrm{~cm}$ (upper generatrix), thus freezing the region.

\section{EXPERIMENTAL EVALUATION BEHAVIOR OF PAFSIN PIPES}

\subsection{Experimental perimeters}

PAFSIN pipeline sample was buried in the usage oil Petrom Zemes in Bacau, Romania at an altitude of $550 \mathrm{~m}$ above sea level, close to a PAFSIN pipeline DN1000, PN10, SN10000 in operation by CRAB Bacau to rate damage is average. Also, another model crash occurred in areas with salty soils (the Amara / Ialomita, the Salt Lake / Braila, Balta Alba / Buzau, Romania but also in adjacent area Targu Ocna Chimcomplex Onesti, made in 1970 in steel protected with bituminous membranes, now in an advanced state of decay. This type of fault does not occur by transferring the radical of the pipeline, but by seepage and discoloration/roughness of the resin without significant damage to the glass fiber. Hence the choice within the second perimeter experimentally in an area known to have a character similar to the above, the valley of Salt Solonț / Bacau, Romania. Sample of PAFSIN pipe was buried in the Solont, Bacău at an altitude of $440 \mathrm{~m}$ above the sea level, in an area valley Sarata with ground presence variable between 0 and $0.50 \mathrm{~m}$. To have a reference system, we chose a third perimeter experimentally in a land that has been installed previously PAF SINpipes not resulting in problems operating the commune Margineni, Bacau, at an altitude of $210 \mathrm{~m}$ above sea level the sea, in a plain alluvial with a slope of less than $5 \%$, unflooded and groundwater at a depth of more than $2 \mathrm{~m}$. After 24 months, samples were dug / recovered, and then in July 2016 subjected to measurements in the laboratory plant piping GRP subordinated in Turkey (analysis of structural composition, test Barcol efforts axial or longitudinal) in September 2016 in the laboratory of the plant Amitech Dresden (rigidity, Barcol Test). Of the land that has been installed in the pipe samples were

where: 
removed from their proximity in the structure disturbed. These samples were subjected to laboratory analysis OSPA set of Iaşi.

\subsection{Results}

Of the three pipes were cut in the longitudinal direction by 5 test pieces with a width of about $25 \mathrm{~mm}$, length $200 \mathrm{~mm}$, with the thickness of the pipe (about $4.4 \mathrm{~mm}$ ). The results are provided in Tables 1, 3, 4, 5 and Figures 2, 4, 6. The symbols in the tables: $\mathrm{E}$ is the pipe wall thickness; $\mathrm{w}$ is the width of the sample; $\chi$ mean value of the five measurements, and the standard deviation, the standard deviation $v$ percent. Missing values in the table is due to read errors as those defendants automatic offset program data processing by interpolation.

Table 1. The test results in axial - neutral sample

\begin{tabular}{|c|c|c|c|c|c|c|c|c|c|}
\hline 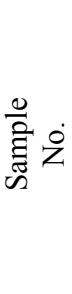 & ఏ્छ & $\frac{\widehat{\Xi}}{\text { ह્ }}$ & 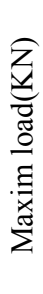 & 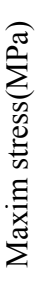 & 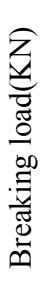 & 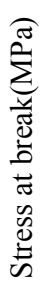 & 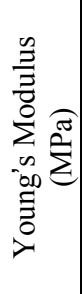 & 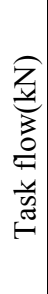 & 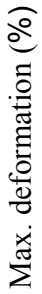 \\
\hline 1 & $\stackrel{?}{\forall}$ & 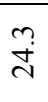 & in & $\begin{array}{l}\infty \\
\stackrel{q}{q}\end{array}$ & $\vec{\sim}$ & 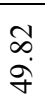 & 点 & $\underset{\nabla}{\stackrel{\mathbb{V}}{+}}$ & 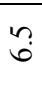 \\
\hline 2 & $\stackrel{n}{\forall}$ & $\approx$ & $\begin{array}{l}\text { ô. } \\
\text { in }\end{array}$ & $\begin{array}{l}0 \\
\dot{y}\end{array}$ & $\begin{array}{l}\text { ô. } \\
\text { in }\end{array}$ & $\begin{array}{l}0 \\
\dot{f}\end{array}$ & જิ & $\begin{array}{l}\sigma \\
\text { in }\end{array}$ & $\overrightarrow{6}$ \\
\hline 3 & $\stackrel{n}{r}$ & $\vec{n}$ & ô. & $\stackrel{n}{f}$ & $\begin{array}{c}0 \\
\text { in } \\
\text {. }\end{array}$ & $\stackrel{n}{f}$ & हิ & & $\stackrel{\nabla}{\circ}$ \\
\hline 4 & $\underset{+}{+}$ & 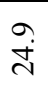 & $\begin{array}{r}\infty \\
\dot{\sigma}\end{array}$ & $\stackrel{\sim}{\mathcal{\gamma}}$ & $\hat{\infty}$ & $\begin{array}{l}\tilde{n} \\
\text { y }\end{array}$ & $\stackrel{\infty}{8}$ & $\begin{array}{l}n \\
\ddot{\sigma}\end{array}$ & છे \\
\hline 5 & $\stackrel{+}{+}$ & $\approx$ & $\begin{array}{l}n \\
n \\
n\end{array}$ & $\begin{array}{l}n \\
\ddot{n}\end{array}$ & $\begin{array}{l}n \\
n \\
n\end{array}$ & $\begin{array}{l}\text { f. } \\
\stackrel{\circ}{n}\end{array}$ & 导 & 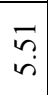 & $\stackrel{?}{n}$ \\
\hline \multicolumn{10}{|c|}{ Statistical Analysis } \\
\hline $\mathrm{X}$ & $\begin{array}{l}\circ \\
+ \\
+\end{array}$ & $\begin{array}{l}\stackrel{0}{\infty} \\
\dot{+}\end{array}$ & $\frac{m}{n}$ & 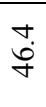 & $\stackrel{m}{n}$ & 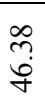 & $\underset{\sigma}{\mathbb{V}}$ & $\begin{array}{l}\stackrel{n}{q} \\
\dot{\gamma}\end{array}$ & $\ddot{0}$ \\
\hline $\mathrm{S}_{\mathrm{i}}$ & $\underset{\Xi}{\Xi}$ & 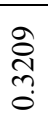 & ָ̊ & $\stackrel{+}{n}$ & $\begin{array}{l}\text { तै } \\
\text { กै }\end{array}$ & $\stackrel{+}{n}$ & $\frac{1}{n}$ & $\begin{array}{l}\vec{\jmath} \\
\stackrel{0}{0}\end{array}$ & f̊ \\
\hline $\mathrm{N}$ & $\begin{array}{l}\stackrel{0}{n} \\
i\end{array}$ & సે & ò & $\underset{\sim}{n}$ & $\begin{array}{l}\text { oे. } \\
\text { in }\end{array}$ & $\underset{r}{\tilde{r}}$ & $\bar{n}$ & $\vec{n}$ & $\underset{\sim}{\sim}$ \\
\hline
\end{tabular}

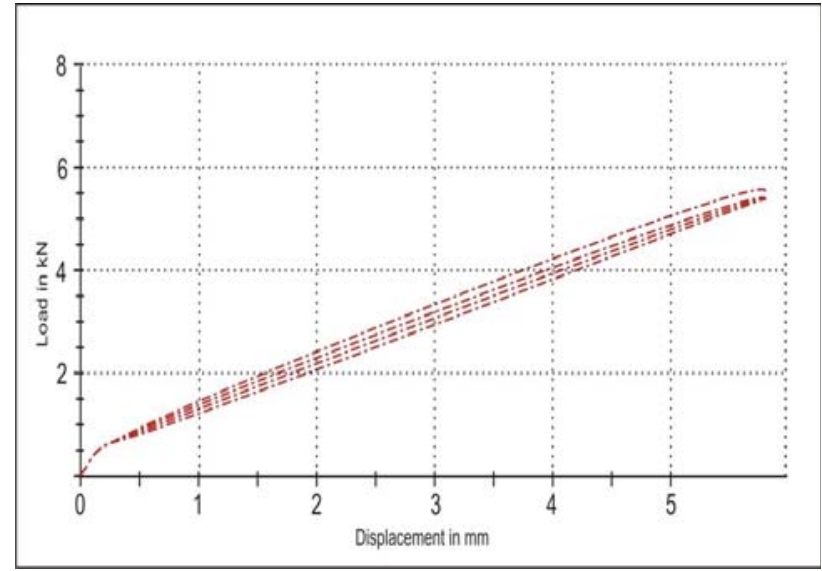

Figure 2. The deformation of the sample, neutral ground load

Table 3. The test results in axial - alkali land sample

\begin{tabular}{|c|c|c|c|c|c|c|c|c|c|}
\hline 莺 & $\underset{\text { 哥 }}{\widehat{\Xi}}$ & $\frac{\widehat{\Xi}}{\text { 㤩 }}$ & 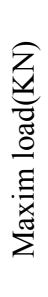 & 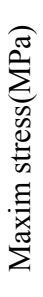 & 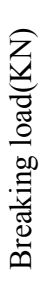 & 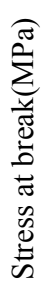 & 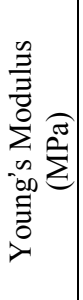 & 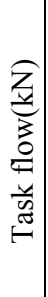 & 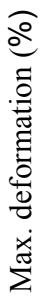 \\
\hline 1 & $\stackrel{\sim}{\sim}$ & $\stackrel{?}{\stackrel{\sim}{\sim}}$ & $\stackrel{\text { f }}{+}$ & $\begin{array}{l}\infty \\
\dot{\gamma}\end{array}$ & $\stackrel{\text { f }}{\stackrel{\gamma}{*}}$ & $\begin{array}{l}\stackrel{\infty}{\stackrel{y}{\vartheta}} \\
\frac{\dot{y}}{2}\end{array}$ & $\frac{n}{a}$ & $\stackrel{0}{\stackrel{+}{+}}$ & $\stackrel{n}{+}$ \\
\hline 2 & $\stackrel{\vartheta}{\forall}$ & $\stackrel{\sim}{\sim}$ & $\begin{array}{l}n \\
\stackrel{n}{+}\end{array}$ & $\stackrel{\infty}{\stackrel{\sim}{f}}$ & $\begin{array}{l}n \\
\sim \\
\forall\end{array}$ & $\begin{array}{l}\underset{J}{\infty} \\
\stackrel{I}{f}\end{array}$ & $\frac{\infty}{\infty}$ & 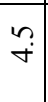 & $\vec{i}$ \\
\hline 3 & $\stackrel{+}{\forall}$ & $\stackrel{\sim}{\sim}$ & $\dddot{r}$ & 守 & $\dddot{\sim}$ & $\underset{\nabla}{\vec{\gamma}}$ & $\overline{8}$ & $\stackrel{\ominus}{\stackrel{\sim}{+}}$ & $\begin{array}{l}\bullet \\
+\end{array}$ \\
\hline 4 & $\stackrel{\vartheta}{\forall}$ & $\begin{array}{l}0 \\
\stackrel{\sim}{d}\end{array}$ & $\begin{array}{l}\mathscr{n} \\
\dot{\gamma}\end{array}$ & $\underset{\infty}{\infty}$ & $\begin{array}{l}\mathscr{n} \\
\dot{\forall}\end{array}$ & 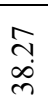 & হू & 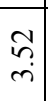 & $\stackrel{\vartheta}{\nabla}$ \\
\hline 5 & $\stackrel{n}{\forall}$ & $\stackrel{\stackrel{\sim}{d}}{\stackrel{+}{~}}$ & $\begin{array}{l}\dot{\sigma} \\
\text { ले }\end{array}$ & $\begin{array}{l}\infty \\
\dot{n} \\
\dot{n}\end{array}$ & बे & $\begin{array}{l}\infty \\
\infty \\
m\end{array}$ & $\underset{N}{n}$ & $\begin{array}{l}\stackrel{\circ}{2} \\
\dot{r}\end{array}$ & $\stackrel{m}{+}$ \\
\hline \multicolumn{10}{|c|}{ Statistical Analysis } \\
\hline $\mathrm{X}$ & $\stackrel{⿱ 亠 乂}{\stackrel{*}{*}}$ & $\stackrel{n}{\stackrel{n}{d}}$ & $\frac{m}{n}$ & 年 & $\stackrel{?}{+}$ & $\begin{array}{l}\stackrel{+}{q} \\
\stackrel{f}{ }\end{array}$ & $\underset{\infty}{\infty}$ & $\stackrel{\partial}{\curvearrowright}$ & $\stackrel{F}{F}$ \\
\hline $\mathrm{S}_{\mathrm{i}}$ & $\stackrel{ \pm}{\exists}$ & $\begin{array}{l}\infty \\
\stackrel{n}{0} \\
\ddot{0}\end{array}$ & స̃ & $\stackrel{m}{m}$ & 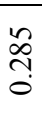 & $\stackrel{m}{m}$ & 市 & $\stackrel{n}{\hat{n}}$ & $?$ \\
\hline $\mathrm{N}$ & $\begin{array}{l}\hat{b} \\
\stackrel{i}{ }\end{array}$ & $\underset{\ddot{\sigma}}{\mathscr{n}}$ & $\begin{array}{l}\text { oे } \\
\text { in }\end{array}$ & $\underset{\infty}{\stackrel{N}{ }}$ & $\begin{array}{l}\hat{\sigma} \\
0\end{array}$ & $\underset{\infty}{\infty}$ & $\begin{array}{l}\text { fa } \\
\text { ă }\end{array}$ & 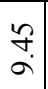 & 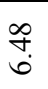 \\
\hline
\end{tabular}




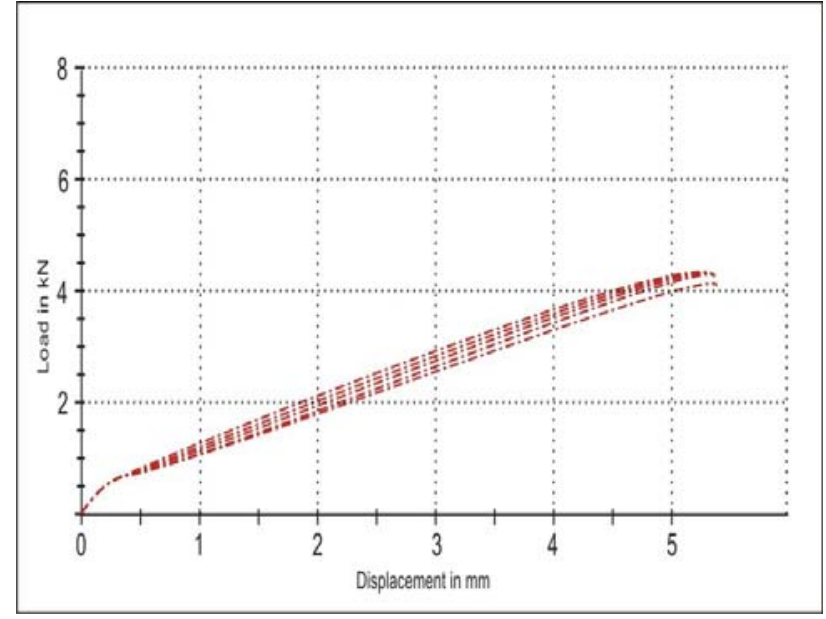

Figure 4 . The deformation of the sample, alkali ground load

Table 5. The test results in axial - sample acid land

\begin{tabular}{|c|c|c|c|c|c|c|c|c|c|}
\hline 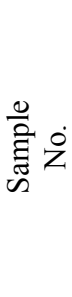 & 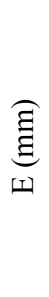 & $\frac{\widehat{\Xi}}{3}$ & 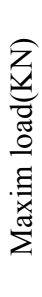 & 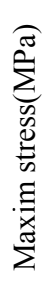 & 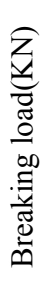 & 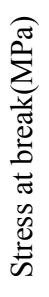 & 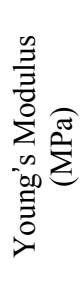 & 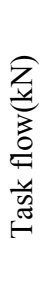 & 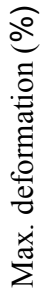 \\
\hline 1 & $\stackrel{n}{*}$ & 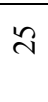 & $\stackrel{\vec{\sigma}}{+}$ & $\vec{n}$ & $\stackrel{\vec{\sigma}}{\overrightarrow{+}}$ & $\begin{array}{l}\stackrel{0}{0} \\
i \\
\tilde{n}\end{array}$ & ○ & ळे & $\stackrel{\nabla}{\forall}$ \\
\hline 2 & $\begin{array}{l}\stackrel{\bullet}{+} \\
\stackrel{+}{*}\end{array}$ & $\begin{array}{l}\stackrel{0}{+} \\
\stackrel{+}{~}\end{array}$ & $\stackrel{\Re}{\stackrel{\overbrace{}}{+}}$ & $\stackrel{\infty}{\dot{\nabla}}$ & $\stackrel{\Re}{\stackrel{\overbrace{}}{+}}$ & $\begin{array}{l}\vec{\infty} \\
\vec{\forall}\end{array}$ & $\underset{\infty}{+}$ & $\stackrel{n}{m}$ & $\begin{array}{l}0 \\
i\end{array}$ \\
\hline 3 & $\stackrel{F}{F}$ & $\stackrel{\check{d}}{\dot{d}}$ & $\begin{array}{l}\hat{\sigma} \\
\dot{\gamma}\end{array}$ & ֻ̊ & $\begin{array}{l}\hat{\sigma} \\
\dot{\sigma}\end{array}$ & $\begin{array}{l}\text { N̦ } \\
\stackrel{q}{+}\end{array}$ & $\underset{\infty}{\infty}$ & $\underset{+}{\stackrel{\leftrightarrow}{+}}$ & $\stackrel{0}{n}$ \\
\hline 4 & $\stackrel{n}{+}$ & $\stackrel{+}{\stackrel{+}{\sim}}$ & $\underset{\nabla}{\nabla}$ & $\stackrel{\overbrace{}}{\text { ণ }}$ & $\vec{\nabla}$ & \begin{tabular}{l}
$\infty$ \\
$\infty$ \\
\multirow{f}{*}{}
\end{tabular} & $\underset{\infty}{\mathbb{\infty}}$ & $\begin{array}{l}\hat{\sigma} \\
\dot{+}\end{array}$ & $\stackrel{r}{F}$ \\
\hline 5 & $\begin{array}{l}\stackrel{\circ}{+}\end{array}$ & $\begin{array}{l}0 \\
\stackrel{+}{\sim}\end{array}$ & $\stackrel{n}{\rightleftharpoons}$ & $\hat{\sigma}$ & $\stackrel{n}{\underset{f}{*}}$ & i் & $\frac{2}{2}$ & $\begin{array}{l}\stackrel{\partial}{+} \\
\stackrel{+}{*}\end{array}$ & $\begin{array}{l}\underset{+}{+} \\
\stackrel{1}{*}\end{array}$ \\
\hline \multicolumn{10}{|c|}{ Statistical Analysis } \\
\hline $\mathrm{X}$ & $\begin{array}{l}\infty \\
\sim \\
\forall\end{array}$ & $\begin{array}{l}\stackrel{0}{0} \\
\dot{\sim}\end{array}$ & $\stackrel{n}{\stackrel{n}{f}}$ & هे. & $\stackrel{\sim}{\stackrel{n}{f}}$ & $\begin{array}{l}\stackrel{n}{\circ} \\
\stackrel{m}{m}\end{array}$ & $\underset{\infty}{\sharp}$ & $\vec{m}$ & F \\
\hline$\overline{\mathrm{S}_{\mathrm{i}}}$ & $\begin{array}{l}\mathscr{\infty} \\
\stackrel{\infty}{0} \\
0\end{array}$ & $\begin{array}{l}\bar{a} \\
\overline{0}\end{array}$ & m? & $\frac{n}{m}$ & 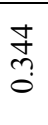 & $\frac{n}{n}$ & $\underset{\infty}{\infty}$ & $?$ & ֶ̃? \\
\hline $\mathrm{N}$ & $\stackrel{\infty}{\infty}$ & $\stackrel{\infty}{\infty}$ & $\stackrel{\Re}{r}$ & $\infty$ & $\stackrel{m}{r}$ & $\infty$ & $\underset{i n}{\stackrel{N}{i}}$ & $\hat{\sigma}$ & $\underset{i n}{\stackrel{ \pm}{n}}$ \\
\hline
\end{tabular}

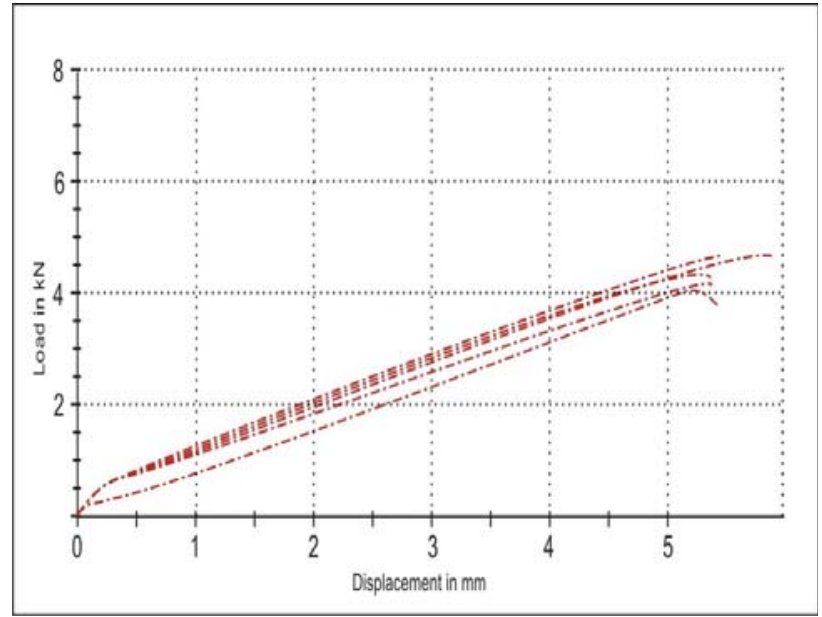

Figure 6 . The deformation of the sample, acid ground load

\subsection{Results interpretation}

Centralization of efforts of average values (stresses), the maximum strain, Young's modulus and load at yield are shown in Table 7 and Figure 8.

Table 7.The axial averages

\begin{tabular}{|l|c|c|c|}
\hline \multicolumn{1}{|c|}{ Size } & $\begin{array}{c}\text { Neutral } \\
\text { sample }\end{array}$ & $\begin{array}{c}\text { Sample } \\
\text { basic land }\end{array}$ & $\begin{array}{c}\text { Sample } \\
\text { acid land }\end{array}$ \\
\hline $\begin{array}{l}\text { Max. } \\
\text { deformat.(\%) }\end{array}$ & 6.60 & 4.70 & 4.70 \\
\hline Task flow(kN) & 4.95 & 3.99 & 4.31 \\
\hline $\begin{array}{l}\text { Young's } \\
\text { Modulus(MPa) }\end{array}$ & 672 & 852 & 844 \\
\hline $\begin{array}{l}\text { Stress at } \\
\text { break(MPa) }\end{array}$ & 46.38 & 40.50 & 39.45 \\
\hline Stress(MPa) & 46.4 & 40.50 & 39.45 \\
\hline
\end{tabular}

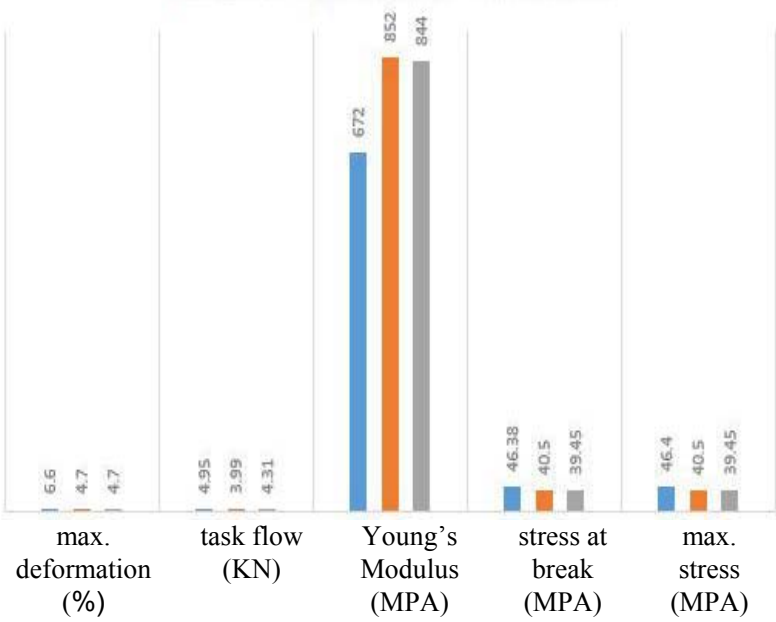

Figure 8. Depending on the characteristics of the measured axial variation of pitch 
Axial breaking stress values, namely the flow, particularly practical interest because of specific situations that occur relatively frequently in operation, such as that due to the spread of the hydromechanical portion of the bed is washed laying, the pipes remain. The lower generatrix of such ducts tensile stresses occur (working as a double girder resting) that can compromise the pipe, especially in the case of prior damage to the pipe. Another example is the pressure jacks blocked networks (such as hydropower), where the future changes of direction / axial alignment can cause significant effort (Mahmoud et al. 2003).

A check of the maximum axial force required by the standard PAFSIN pipes is required by the formula:

$$
\sigma_{i} \equiv 25 * P N * d_{m}
$$

where: $\sigma_{i}$ is the initial minimum value of the maximum axial effort (in $\mathrm{MPa}$ ), $P N$ it is the nominal pressure, $d_{m}$ it is the average diameter of the pipe tested (in $\mathrm{m}$ ).

$$
\sigma_{i} \equiv 25 * 10 * 0.15 \equiv 37.5(M P a)
$$

All three samples were tested condition standard, the measured values are higher.

\section{CONCLUSIONS}

The mechanism of degradation of the pipes differs from the basic to acidic soils, such:

- the lands acid degradation occurs to the outside of the resin liner, reflected by increased roughness, surface micro-cracks, change of color (darken the color, aging-specific) . Fiberglassresin matrix is impaired, resulting in significantly lower values of some sizes essentials like maximum deflection and effort to tear more pronounced decrease in the circumferential direction, suggesting local degradation / point of fiberglass continuous practical effect of lowering the ability to retrieve the internal pressure of the fluid in the case pressure pipes. An increase in the axial direction of the Young's modulus, therefore, a turning semi-elastic behavior of the rigid pipe, and this increase did not occur in the circumferential direction. The stiffness measured in the transverse direction undergoes a significant decrease, significantly less than the base pitch. Hence not affecting the normal life of the pipes laid in this field.

- in the basic fields, the most important phenomenon that stands out is to increase the Young's modulus in both directions, axial and circumferential. This practice is of exceptional importance, since it changes the behavior of the pipe in one semi-elastic rigid capacity to work with the ground in the vicinity of the duct disappears, thereby working independently pipe. However, due to the manner of engagement with the sockets, which can be assimilated to the elastic joints, loss of elasticity in the axial direction is compensated for. Conversely, increasing the value of Young's Modulus will affect substantially the circumferential extent of the pipes under pressure. Even if the breaking pressure values will not be affected, rigid behavior of the composite would be vulnerable to sudden variations in pipe internal pressure. Pearson correlation coefficients for $\mathrm{pH}$ confirm the increase of the Young's modulus proportional to it. The stiffness of the pipe measured in the transverse direction decreases significantly (more than the land acid).

In the field of analysis of experimental data, it would be useful to develop the concept of residual chemical stress, to introduce a quantization factor of structural degradation products of chemical attacks on the tubes.

\section{REFERENCES}

Adams, R.D., Cawley, P.D., 1998. A review of defect types and non-destructives testing techniques for composites and bonded joints. Non Destructive Techniques Int., 21:208-22.

Akimwumi, I.I., Diwa, D., 2014. Effects of crude oil contamination on the index properties, strength and permeability of lateritic clay. Int. Journal of applied sciences and engineering research, vol. 3 no. 4 .

Cojocaru, G., 2017. Experimental investigations on the effect of soil pH on GRP buried pipes. Sub-urban - A European network to improve understanding and use of the ground beneath our cities, Bucharest.

David-West, O.S., Nash, D.H.; Banks, W.M., 2008. An experimental study of damage accumulation in balanced CFRP laminates due to repeated impact. Composites Structures, 83:247-58.

Hornung, K., Kittel, D., 2010. Statik erduberdeckter Rohre. Bauverlag, Wiesbaden.

Isama, L., 2013. Effects of crude oil spillage on soil physicochemical properties in Ugborodo community. International journal of modern engineering research, pp. 3336-3342.

Mahmoud, M.K., Tantawi, M.K., 2003. Effects of strong acids on mechanical properties of GRP pipes at normal and high temperatures. Polym Plast Technol Eng, 42:677-88.

Mateescu, T., Profire, M., Pop, A., Ciascai I., 2000. Conducte din mase plastice pentru sisteme de utilități urbane.Ed. Revox, Bistrița.

Mertiny, P., Ursinus, K., 2007. A methodology for assesing fatigue degradation of glass reinforced composites conductes. Polymere Testing, 26:751-760.

Moser, Alma P., 2001. Buried Pipe Design. McGraw-Hill, New York

Rafiee, R., 2013. Experimental and theoretical investigations on the failure of GRP pipes. Composites PartB, 45:257-267.

Renoud, W., Moubarac, R., 2009. In search of the optimum pipe material for seawater services. Fiberglass Structural Engineering, Washington.

Shukry, W.M., Al-Hawas, G.H.S., Al-Moaikal, R.M.S., ElBendary, M.A., 2013. Effect of petroleum crude oil on mineral nutrient elements, soil properties and bacterial biomass. British journal of environment and climate change, pp.103-118. 
Sindhu, K., Joseph, K., Joseph, J.M., Mathew, T. V., 2007. Degradation studies of coir fiber/polyester and glass fiber/polyester composites under different conditions. Journal of Reinf. Plastic composites, 26:1571-85.

Stamenovic, M., Putic, S., Rakin, M., 2011. Effect of alkaline and acid solutions on the tensile properties of GRP pipes. Mater Design, 32:2456-61.

Wang, Y., Feng, J., Lin, Q., Lyu, X., Wang, X., Wang, G., 2013. Effects of crude oil contamination on soil physical and chemical properties in Momoge wetland of China. China Geografical Sciences, 23:708-715. 